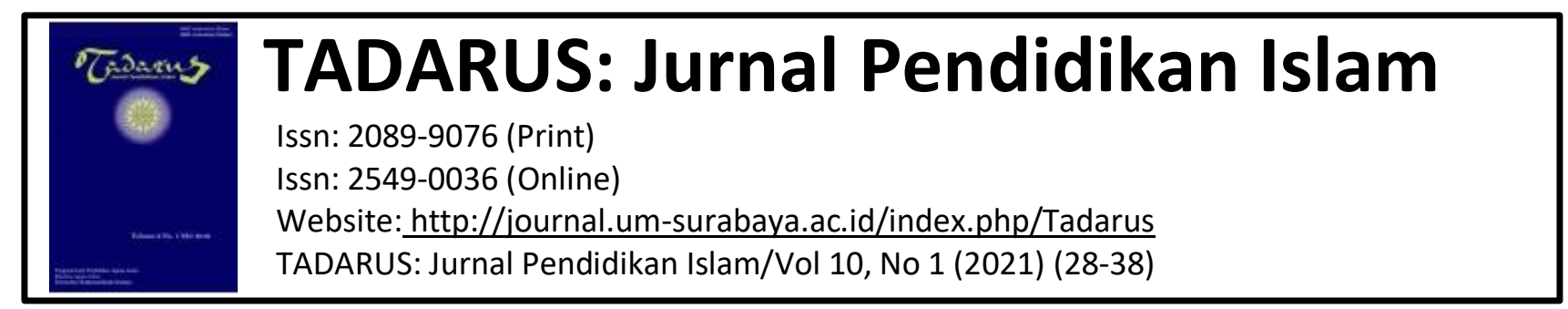

\title{
IMPLEMENTASI PROGRAM PEMBIASAAN TADARUS AL-QUR'AN DALAM \\ PEMBINAAN CINTA AL-QUR'AN OLEH SISWA DI SMP \\ MUHAMMADIYAH 15 LAMONGAN
}

\author{
Din Muhammad Zakariya \\ dinmzakariya70@gmail.com
}

\begin{abstract}
Abstrak
Penelitian ini bertujuan untuk menggali tentang implementasi program pembiasaan tadarus al-Qur'an dalam pembinaan cinta al-Qur'an oleh siswa di SMP Muhammadiyah 15 Lamongan. Jenis penelitian ini menggunakan penelitian kualitatif, dengan pendekatan deskriptif. Proses pengumpulan data dilakukan dengan menggunakan instrument observasi, wawancara dan dokumentasi. Data yang telah terkumpul kemudian dilakukan analisis data dengan tahap pengumpulan, reduksi, dan penyajian data dan penarikan kesimpulan sesuai dengan ruang lingkup permasalahan. Hasil penelitian ini menunjukkan bahwa program pembiasaan tadarus Al- Qur'an di SMP Muhammadiyah 15 Lamongan adalah sebuah pembiasaan bagi siswa untuk membaca Al-Qur'an yang dilaksanakan setiap pagi sebelum memulai pelajaran, Program pembiasaan tadarus Al-Qur'an ini bertujuan untuk membentuk karakter islami siswa yang lebih mencintai Al-Qur'an dengan senang membaca atau menyimaknya. Untuk itu kegiatan ini menjadi tradisi yang dipandang cocok bagi siswa dalam kegiatan keagamaan dan menjadi sarana pembiasaan yang baik di aktivitas sehari-hari dalam ranah keagamaan yang mengarah kepada pendekatan terhadap kitab Al-Qur'an.
\end{abstract}

Kata Kunci: Tadarus al-Qur'an, Pembiasaan, Pembinaan Cinta al-Qur'an

\section{PENDAHULUAN}

Pada era globalisasi ini, ilmu pengetahuan dan teknologi berkembang sangat pesat. Perkembangan kian merambah ke segala bidang. Seperti teknologi internet, berkembang menjadi media informasi sampai dengan media sosial yang marak dipergunakan dalam kehidupan manusia saat ini. Hal ini membuat manusia terseret dengan kemajuan yang mengurangi aktivitas keagamaan, seperti lunturnya 
kedisiplinan dalam beribadah, jarangnya mengikuti majelis keagamaan, hilangnya kebiasaan membaca kitab Al-Qur'an dan banyak yang lainnya. Menjadi tantangan yang besar bagi manusia untuk menyikapinya. Maka dari itu pendidikan adalah alat dalam menjawab akan dampak-dampak negatif tersebut, terkhususnya Pendidikan Agama Islam, yang lebih khusus dalam meluruskan dan menjaga kehidupan manusia.

Pendidikan agama yang dapat menghasilkan perbaikan moral,harus diubah dari model pengajaran agama kepada pendidikan agama. Pengajaran agama dapat berarti transfer of religion knowledge (mengalihkan pengetahuan agama) atau mengisi anak dengan pengetahuan tentang agama, sedangkan pendidikan agama bisa berarti membina dan mewujudkan perilaku manusia yang sesuai dengan tuntunan agama. ${ }^{1}$

Menurut Omar Muhammad At-Toumy Asy-Syaibany mengartikan pendidikan Islam sebagai perubahan yang diinginkan dan diusahakan oleh proses pendidikan, baik pada tataran tingkah laku individu maupun pada tataran kehidupan sosial serta pada tataran relasi dengan alam sekitar. ${ }^{2}$

Melihat dampak-dampak akan kemajuan teknologi seperti munculnya internet, pesatnya media sosial, permainan-permainan online, dan lain-lain, yang membuat kebiasaan baru bagi manusia, sehingga berkurangnya aktivitas keagamaan, salah satunya adalah membaca Al-Qur'an. Untuk itu dalam mencapai tujuan pendidikan dengan tertanamnya kepribadian yang beragama pada peserta didik di SMP Muhammadiyah 15 Lamongan, maka dibentuklah sebuah program pembiasaan yang bersifat religious atau keagamaan, seperti melaksanakan Tadarus Al-Qur'an atau membaca/menyimak ayat- ayat Al-Qur'an setiap pagi sebelum melaksanakan proses belajar mengajar di kelas. Karena dengan pembiasaan membaca Al-Qur'an, akan mengajak siswa/peserta didik dengan lebih taat kepada Allah SWT, khususnya pembinaan dalam mencintai Al- Qur'an.

Sudah semestinya, menurut Ustadz Umay Djca'far Shiddiq, sejak usia dini seseorang yang beragama Islam harus berawal dari pemahaman terhadap induk

\footnotetext{
${ }^{1}$ Abuddin Nata, Manajemen Pendidikan Cet. 4, (Jakarta : Kencana, 2010), hlm. 207-208

${ }^{2}$ Mahmud, Pemikiran Pendidikan Islam, (Bandung : Pustaka Setia, 2011), hlm. 24
} 
ajarannya terlebih dahulu apalagi sudah dijamin kebenarannya oleh Allah SWT yaitu Al-Qur'an, baru berikutnya hadits, baru kemudian fatwa-fatwa ulama. ${ }^{3}$

Berdasarkan observasi awal dan melihat penjelasan di atas, telah tergambar bahwa pada SMP Muhammadiyah 15 Lamongan, telah melaksanakan usaha dalam meningkatkan mutu pendidikan bagi siswa/peserta didik, yang mengarah kepada Pendidikan Agama Islam. Maka dari itu peneliti ingin mengetahui sejauhmana program pembiasaan yang bersifat religious atau bernuansa keagamaan tersebut, khususnya pembiasaan Tadarus Al-Qur'an ini dapat membina siswa yang lebih mencintai Al-Qur'an itu sendiri.

Dari latar belakang masalah diatas, penulis ingin mengadakan penelitian dengan judul 'Implementasi Program Pembiasaan Tadarus Al-Qur'an dalam Pembinaan Cinta Al-Qur'an oleh Siswa di SMP Muhammadiyah 15 Lamongan”

\section{METODE PENELITIAN}

Penelitian ini menggunakan metode Kualitatif. Hal ini disebabkan dalam penelitian ini melihat secara alamiah bagaimana berbagai proses dan realita yang terjadi di lapangan. Menurut Sugiyono dalam penelitian kualitatif peneliti sebagai human instrument dan dengan teknik pengumpulan data participant observation (observasi berperan serta) dan in depth Interview (wawancara mendalam), maka peneliti harus berinteraksi dengan sumber data. Dengan demikian peneliti kualitatif harus mengenal betul orang yang memberikan data. ${ }^{4}$

Peneliti menggunakan Metode kualitatif dengan pendekatan deskriptif. Menurut Sugiyono metode kualitatif deskriptif adalah menganalisis data dengan cara mendeskripsikan atau menggambarkan data yang telah terkumpul sebagaimana adanya tanpa bermaksud membuat kesimpulan yang berlaku untuk umum atau generalisasi. ${ }^{5}$ Metode kualitatif menyajikan secara langsung hakikat hubungan antara peneliti dan informan, objek dan subjek penelitian.

Menurut Bogdan dan Biklen dalam Sugiyono Penelitian kualitatif memiliki beberapa ciri-ciri diantaranya: ${ }^{6}$

\footnotetext{
${ }^{3}$ Masagus Fauzan Yayan, Kiat Jitu Bersahabat dengan Al-Qur'an, cet. Ke-1 (Jakarta : Sahabat Qur'an, 2008), hlm. 65

${ }^{4}$ Sugiyono, Metode Penelitian Kuantitaif Kualitatif Dan R\&D, (Bandung: Alfabeta Cv, 2011), 11

${ }^{5}$ Ibid.

${ }^{6}$ Ibid.
} 
1. Peneliti sendiri sebagai instrument utama untuk mendatangi secara langsung sumber data

2. Mengimplementasikan data yang dikumpulkan dalam penelitian ini lebih cenderung kata-kata daripada angka

3. Menjelaskan bahwa hasil penelitian lebih menekankan kepada proses tidak semata-mata kepada hasil

4. Melalui analisis induktif, peneliti mengungkapkan makna dari keadaan yang terjadi

5. Mengungkapkan makna dari hal yang esensial dari pendekatan kualitatif

Penelitian ini menggunakan sumber data baik secara primer ataupun sekunder. Sumber data primer merupakan data yang utama yang menjadi sentral dalam penelitian ini. Sumber data primer sendiri dalam penelitian dengan pendekatan kualitatif ini tentunya berasal dari informan dan narasumber dilapangan dan hasil pengambilan berbagai instrument dalam penelitian. Informan dan narasumber dilapangan berasal dari Kepala Sekolah, Waka Kurikulum, Sarpras, Ismuba, Kesiswaan, BK dan Guru.

Sebagai data pendukung digunakan sumber data sekunder dari berbagai kajian pustaka. Kajian pustaka dari berbagai sumber baik dari sisi teori dan berbagai para pendapat ahli yang dijadikan peneliti sebagai landasan dalam penelitian. Secara lebih lanjut sumber data sekunder yang digunakan misalnya dokumen sekolah diantaranya keadaan geografis sekolah, profil sekolah, program kerja sekolah dll.

\section{HASIL PENELITIAN DAN PEMBAHASAN}

\section{Pembinaan Cinta Al-Qur'an}

Pembinaan adalah suatu usaha dalam membentuk peserta didik, dalam mencapai tujuan dari pendidikan itu sendiri. Pembinaan adalah dari kata bina, Dalam Kamus Besar Bahasa Indonesia, bina, sama dengan membina, atau membangun. ${ }^{7}$ Di dalam kamus besar Bahasa Indonesia,kata“cinta”berarti rasa sangat kasih sayang atau sangat tertarik hatinya, atau selalu mengingatkan akan yang dicintainya. ${ }^{8}$

${ }^{7}$ Tim penyusun, Op.Cit, hlm. 128

${ }^{8}$ Ibid, hlm. 160 
Kamus Besar Bahasa Arab, kata Hubbul berarti, Mengasihi, mencintai. ${ }^{9}$ "Perkataan“cinta"berasal dari Al-Qur'an ,al-hubb atau mahabbah,cinta kasih sayang. ${ }^{10}$ Mencintai Al-Qur'an sama halnya mencintai Allah SWT dan Rasul-Nya dalam artian taat kepada Allah dan Rasul, salah satunya contohnya adalah gemar membaca Al- Qur'an. Orang-orang yang mencintai Al-Qur'an, akan mempunyai ciri-ciri dihatinya. Hati yang mencintai Al-Qur'an mempunyai beberapa ciri, diantaranya :

a. Senang bertemu dengan Al-Qur'an

b. Selalu duduk bersama Al-Qur'an dalam jangka waktu yang lama tanpa dihinggapi rasa bosan

c. Selalu rindu untuk bertemu setiap kali berjauhan dan selalu berusaha

d. menghilangkan aral melintang yang memisahkannya.

e. Senantiasa berdialog, menerima arahan-arahan dari Al-Qur'an itu sendiri, serta menaati perintah dan menjauhi larangannya. ${ }^{11}$

Membaca Al-Qur'an Sebaiknya, sesorang dalam keadaan berwudhu dan bersikap sopan berdiri atau duduk. Yang paling utama adalah membacanya di waktu sholat sambil berdiri. ${ }^{12}$ Dalam mendidik anak agar mencintai Al-Qur'an, mesti menggunakan metode- metode yang sesuai dengan usianya. Seperti didahulukan dengan pemberian penjelasan tentang pentingnya Al-Qur'an bagi kehidupan di dunia dan di akhirat, menjelaskan keutamaan membaca, menghafal, dan mengerti arti dan maknanya, serta memberikan hadits-hadits yang memotivasi anak untuk mempelajari Al-Qur'an.

Al-Qur'an adalah sumber utama hukum Islam, dan juga menjadi pedoman akan kehidupan umat manusia. Telah banyak cara atau metode yang digunakan untuk mempelajari Al-Qur'an, seperti metode membaca Al-Qur'an, tafsir AlQur'an, dan sebagainya. Namun masih banyak yang tidak ingin mempelajari AlQur'an, disamping kesibukan-kesibukan sampai dengan beralihnya era yang menjadi modern. Maka dari itu manusia mesti mempunyai rasa mencintai

\footnotetext{
${ }^{9}$ Amalia Hasanah, Op. Cit., hlm. 111

${ }^{10}$ Rif'at Syauqi Nawawi, Kepribadian Qur'ani, (Jakarta : Amzah, 2011), hlm. 189

${ }^{11}$ Muhammad Syauman Ar-Ramli, dkk., Nikmatnya Menangis bersama Al-Qur'an (Solo : Istambul, 2015), hlm. 54

${ }^{12}$ Al-Ghazali, Mukhtashar Ihya' Ulumuddin, cet. Ke-II (Jakarta : Amani, 2007), hlm.116
} 
terhadap Al-Qur'an, agar dapat maksimal dalam mempelajari Al-Qur'an, salah satunya seperti tadarus Al-Qur'an.

\section{Program pembiasaan tadarus Al-Qur'an di SMP Muhammadiyah 15}

\section{Lamongan}

a. Sasaran dan tujuan program pembiasaan tadarus Al-Qur'an di SMP Muhammadiyah 15 Lamongan

Moch. Subhan A, S.Pd.I, mengatakan bahwa sasaran dari program pembiasaan tadarus Al-Qur'an, adalah seluruh umat Islam yang pada khususnya siswa SMP Muhammadiyah 15 Lamongan. Maka dari itu, program ini dijadikan sebuah pembiasaan bagi siswa untuk membaca Al-Qur'an yang dilaksanakan setiap pagi sebelum memulai pelajaran. Kemudian tujuan dari program pembiasaan tadarus Al-Qur'an adalah, untuk sebagai pelajaran khusus dalam belajar membaca Al-Qur'an siswa, di luar pelajaran lain dan juga di luar pelajaran khusus Pendidikan Agama Islam. Agar siswa mendapatkan waktu untuk mempelajari Al-Qur'an.

Hasil wawancara bersama wakil kepala sekolah, Susanti Indah P, S.Pd, bahwa program pembiasaan tadarus Al-Qur'an adalah kegiatan rutin membaca Al- Qur'an bagi siswa yang dipandu oleh guru atau siswa yang bertugas, untuk membaca Al-Qur'an setiap pagi sebelum jam pelajaran dimulai. Program pembiasaan tadarus Al- Qur'an telah disusun dan dilaksanakan dari sejak lama, bahkan sebelum adanya program wajib membaca Al-Qur'an dari dinas pendidikan.Untuk itu dengan telah dibantu akan adanya program langsung dari dinas pendidikan agar dilaksanakannya kegiatan membaca Al-Qur'an sebelum melaksanakan pembelajaran, kegiatan pembiasaan tadarus Al-Qur'an mesti tetap dipertahankan sebagai budaya yang telah lama dilaksanakan, dan selama ini mempunyai hasil yang positif bagi siswa.

Menurut Moch. Subhan A. S.Pd.I, program pembiasaan tadarus Al-Qur'an bertujuan untuk membentuk karakter islami siswa, yang lebih mencintai AlQur'an dengan senang membaca atau menyimaknya. Untuk itu kegiatan ini menjadi tradisi yang dipandang cocok bagi siswa dalam kegiatan keagamaan. Kemudian yang menjadi dasar terbentuknya pengurus IMTAQ dan program tersebut, yakni melihat akan adanya Undang-undang RI No. 20 tahun 2003 tentang Sistem Pendidikan Nasional, Permen Diknas RI No. 39 tahun 2008 
tentang pembinaan kesiswaan dan seterusnya. Kemudian program pembiasaan tadarus Al-Qur'an di SMP Muhammadiyah 15 Lamongan, dipercayakan kepada pembina Iman dan Taqwa (IMTAQ) yang dibentuk di sekolah untuk membina siswa agar dapat lebih mengembangkan kegiatan keagamaan dengan membentuk program-program keagamaan, yang salah satunya adalah program pembiasaan tadarus Al-Qur'an.

Menurut Moch. Subhan A. S.Pd.I, mengatakan bahwa, program pembiasaan tadarus Al-Qur'an adalah program positif yang bersifat keagamaan di sekolah, untuk siswa agar lebih dekat dengan Al-Qur'an. Program pembiasaan tadarus Al-Qur'an juga menjadipatokan diawal masuknya siswa baru, untuk mengetahui tingkat kelancaran dan benar salahnya siswa dalam membaca AlQur'an, setelah itu baru siswa dimatrikulasikan atau dikelompokan untuk masingmasing tingkat kemampuannya dalam membacaAl- Qur'an, kemudian bagi yang memang belum bisa ataupun belum lancar dalam membaca, akan diberikan binaan khusus di ekstra kurikuler qira'ah.

Dengan demikian dapat disimpulkan bahwa, program pembiasaan tadarus Al- Qur'an di SMP Muhammadiyah 15 Lamongan, adalah program yang seiring adanya perubahan- perubahan peningkatan mutu pendidikan, telah dilaksanakan sejak lama sebelum itu. Kemudian program ini dibentuk khusus untuk siswa, agar menjadi sebuahpembiasaan yang baik diaktivitas sehari-hari dalam ranah keagamaan yang mengarahkepada pendekatan terhadap kitab Al-Qur'an.

3. Bentuk pelaksanaan program pembiasaan tadarus Al-Qur'an, sabagai pembinaan bagi siswa dalam mencintai Al-Qur'an di SMP Muhammadiyah 15 Lamongan

a. Waktu pelaksanaan tadarus

Berdasarkan hasil dokumentasi di sekolah, dan wawancara bersama pembina imtaq SMP Muhammadiyah 15 Lamongan, Moch.Subhan A, S.Pd.I, mengatakan bahwa program pembiasaan tadarus Al-Qur'an di SMP Muhammadiyah 15 Lamongan, dilaksanakan setiap hari kecuali hari senin, jumat dan sabtu, dikarenakan jam pagi telah diisi dengan upacara, dan ekstrakurikuler wajib, namun apabila kegiatan tersebut tidak dilaksanakan, maka program tadarus tetap dilaksanakan. Pembiasaan tadarus Al-Qur'an, atau kegiatan mengaji ini,dilaksanakan setiap pagi sebelum dimulainya belajar mengajar pada jam 
pertama. Lama pelaksanaan sekitar 15 sampai dengan 20 menit, dengan membaca ayat-ayat Al-Qur'an, lebih kurang sebanyak 1 lembar penuh Al-Qur'an.

Kemudian pada pelaksanaannya, kegiatan tadarus langsung diikuti oleh seluruh siswa atau seluruh kelas secara bersamaan. Dan dalam proses mengaji, siswa menyimak dan membaca di kelas masing-masing bersama guru atau wali kelasnya, dengan membawa kitab Al-Qur'an pribadinya sendiri. Lalu dipandu dengan satu orang guru atau siswa yang dijadwalkan untuk membaca Al-Qur'an di ruangan khusus dengan memakai pengeras suara atau speakers yang telah terpasang disetiap lantai pada bangunan sekolah.

b. Peran guru-guru

Guru pada dalam mengimplementasikan program pembiasaan tadarus AlQur'an berperan sebagai pembina yang memantau dan membimbing bahkan langsung ikut dalam proses tadarus Al-Qur'an. Terutama guru Pendidikan Agama Islam, selain menjadi koordinator atau pembina IMTAQ di sekolah untuk implementasi program ini. Selain siswa, guru pun diberikan jadwal untuk memimpin atau memandu jalannya tadarus, khususnya guru Pendidikan Agama Islam, kemudian guru-guru lain sudah berada di dalam kelas bersama-sama siswa menyimak ayat Al-Qur'an yang dibacakan sebelum dimulainya jam pertama belajar.

Kemudian selain memandu jalannya tadarus atau yang membacakan Ayatayat Al-Qur'an, guru atau pembina IMTAQ, menjadwalkan bagi siswa untuk dapat memandu tadarus, atau siswa juga dapat membaca Al-Qur'an mempimpin program tadarus,kemudian guru juga mendampingi dalam proses tadarus berlangsung, guna memperhatikan dan memberikan arahan-arahan agar bacaan dapat lancar dan sesuaitajwidnya.

Menurut Moch. Subhan A, S.Pd.I, program pembiasaan tadarus AlQur'an, adalah kegiatan yang sangat baik bagi siswa di SMP Muhammadiyah 15 Lamongan, karena selain tidak ada dampak negatifnya, tadarus Al-Qur'an ini pun sangat digemari oleh siswa sendiri, sehingga dari pihak pembina imtaq membuatkan jadwal khusus bagi siswa untuk dapat bergantian setiap harinya untuk menjadi pemandu atau yang membacakan ayat-ayat Al-Qur'an, dan guru dapat mendampingi siswa yang membaca, agar dapat mengawasi dan membenarkan bacaan-bacaan yang salah. 
c. Surat-surat yang dibaca saat tadarus

Surat-surat yang dibaca adalah urutan ayat-ayat yang dimulai dengan surat Al-Baqarah, sampai dengan mengkhatamkan Al-Qur'an dengan surat An-Nas, kemudian diulang kembali ke surat Al-Baqarah, dan seterusnya. Setiap harinya Setelah pembacaan ayat-ayat dibacakan, salah satu siswa menjadi saritilawah untuk membacakan arti dari ayat-ayat yang telah dibaca. Dan untuk perharinya, tadarus atau membaca dan menyimak bacaan Al-Qur'an, lebih kurang satu lembar halaman Al-Qur'an.

d. Media yang digunakan

Berdasarkan dokumentasi di sekolah, media yang digunakan dalam implementasi program pembiasaan tadarus Al-Qur'an di SMP Muhammadiyah 15 Lamongan adalah Al-Qur'an itu sendiri. Masing-masing siswa telah tugas untuk membawa Al-Qur'an pribadi mereka masing-masing setiap hari, begitupun para guru.

Kemudian untuk pemandu atau yang membaca Al-Qur'an, selain memegang Al-Qur'an untuk dibaca, telah disediakan di ruangan khusus,sebuah microphone atau speaker untuk yang memandu jalannya tadarus, kemudian disetiap lantai pada gedung sekolah telah dipasang pengeras suara yang terhubung dari microphone pemandu, sehingga para siswa dimasing- masing kelas dapat mendengarkan dan menyimak ayat-ayat Al-Qur'an yang dibacakan.

Dengan demikian, implementasi program pembiasaan tadarus Al- Qur'an di SMP Muhammadiyah 15 Lamongan, adalah kegiatan rutin guna membentuk kebiasaan bagi siswa yang lebih mengarah kepada aktivitas keagamaan dengan setiap harinya membaca atau mendekatkan diri bersama kitab Al- Qur'an.

\section{Hasil dari pelaksanaan program pembiasaan tadarus Al-Qur'an}

Telah disampaikan di atas bahwa program tadarus Al-Qur'an adalah program yang sangat baik bagi siswa, karena program ini adalah kegiatan yang termasuk dalam ketaqwaan kepada Allah SWT, yang lebih dekat dengan kitab AlQur'an.

Menurut Hendra. S.Pd.I, bahwa, manfaat dari program pembiasaan tadarus Al- Qur'an bagi siswa adalah terlihat pada siswa, secara pelan-pelan siswa dapat melancarkan bacaan Al-Qur'an mereka,dan selain itu siswa juga mulai dapat membaca secara benar, atau mengikuti tajwidnya. Najwa Armedia mengatakan 
dengan diadakannya tadarus setiap pagi ini,siswa merasa kembali akan kedekatannya dengan Allah SWT,selain itu siswa juga tahu akan benar salahnya mereka dalam membaca Al-Qur'an, dan merasakan ketenangan saat akan menerima pelajaran dijam pertama.

Moch. Subhan A.,S.Pd.I menambahkan,bahwa salah satu hasil dan manfaat dari kegiatan pembiasaan tadarus Al-Qur'an, yang selama ini dilaksanakan, disamping siswa mendapatkan waktu khusus untuk mempelajari Al-Qur'an,siswa juga akan menjadikan kegiatan ini sebagai pembiasaan yang baik dalam kehidupannya. Kemudian manfaat yang lain, siswa telah dapat diikutkan dalam kegiatan perlombaan-perlombaan Qira'ah atau membaca AlQur'an. Walaupun telah diketahui pesaing sangatlah berpengalaman, seperti peserta dari pondok pesantren, dan lain-lain.

Dengan demikian telah jelas, bahwa program pembiasaan tadarus AlQur'an di SMP Muhammadiyah 15 Lamongan, melahirkan hasil yang positif bagi siswa, dengan beberapa penjelasan di atas, memang sangat pantas untuk diaplikasikan dikehidupan sehari-hari dan dimulai dari sejak anak-anak.

\section{KESIMPULAN}

Berdasarkan hasil penelitian yang telah diuraikan maka bisa disimpulkan bahwa program pembiasaan tadarus Al- Qur'an di SMP Muhammadiyah 15 Lamongan adalah sebuah pembiasaan bagi siswa untuk membaca Al-Qur'an yang dilaksanakan setiap pagi sebelum memulai pelajaran, Program pembiasaan tadarus Al-Qur'an ini bertujuan untuk membentuk karakter islami siswa yang lebih mencintai Al-Qur'an dengan senang membaca atau menyimaknya. Untuk itu kegiatan ini menjadi tradisi yang dipandang cocok bagi siswa dalam kegiatan keagamaan dan menjadi sarana pembiasaan yang baik di aktivitas sehari-hari dalam ranah keagamaan yang mengarah kepada pendekatan terhadap kitab AlQur'an. 


\section{REFERENSI}

Al-Ghazali, Mukhtashar Ihya' Ulumuddin, cet. Ke-II Jakarta : Amani, 2007.

Ar-Ramli, Muhammad Syauman, dkk., Nikmatnya Menangis bersama Al-Qur'an Solo : Istambul, 2015

Fauzan, Yayan Masagus, Kiat Jitu Bersahabat dengan Al-Qur'an, cet. Ke-1 Jakarta : Sahabat Qur'an, 2008

Mahmud, Pemikiran Pendidikan Islam, Bandung : Pustaka Setia, 2011

Nata, Abuddin, Manajemen Pendidikan Cet. 4, Jakarta : Kencana, 2010

Nawawi, Rif'at Syauqi, Kepribadian Qur'ani, Jakarta : Amzah, 2011 